\title{
Perancangan Pengembangan Objek Wisata Lubuak Soda Nagari Tambangan Kabupaten Tanah Datar Sumatera Barat
}

\author{
Meri Sufina ${ }^{1}$, Nanda ${ }^{2}$ \\ Teknik, Universitas Putra Indonesia "YPTK" Padang ${ }^{1,2}$ \\ Email: sufinameri88@gmail.com ${ }^{1}$, nanda_nanda@upiyptk.ac.id ${ }^{2}$ \\ DOI: http://dx.doi.org/10.31869/rtj.v4i1.2226
}

\begin{abstract}
Tambangan merupakan salah satu nagari yang termasuk kedalam wilayah sepuluh koto Kabupaten Tanah Datar, provinsi Sumatera Barat. Nagari ini terletak diperbatasan Kota Padang Panjang menuju Tanah Datar, sebelah kanan dari arah Padang Panjang. Nagari tambangan merupakan wilayah yang masih asri yang rata-rata masyarakatnya bertani. Daerah Nagari Tambangan dipenuhi dengan hamparan sawah, ladang, dan pengairan yang jernih. Sumber air yang jernih inilah yang dimanfaatkan sebagai tempat wisata pemandian Lubuak soda. Objek wisata ini mulai dibuka untuk umum bulan Mei tahun 2019. Penamaan soda karena airnya mengeluarkan gelembung-gelembung seperti soda. Pengunjung yang datang sangat ramai, yang tidak hanya warga lokal tetapi juga dari berbagai daerah. Seiring perkembanganya, Objek Wisata Lubuak Soda belum terkelola dengan baik. Banyak tenda-tenda penjual makanan yang dibangun sembarangan. Dan juga terjadi kesalahan dimana pemanfaatan jembatan sebagai lahan parkir. Dan masih banyak infrastruktur yang belum lengkap sebagai objek wisata, seperti tempat ganti pakaian yang hanya berupa tenda terpal sederhana. Selain itu belum tersedia toilet umum yang memadai, yang ada hanya wc yang masih tradisional berdinding terpal dan dengan pemanfaatan air sungai sebagai pembuangan akhir. Untuk itu penulis ingin mengembangkan bagaimana perancangan pemandian lubuak soda agar lebih tertata rapi, bersih dan lengkap.
\end{abstract}

Keywords: Lubuak Soda, Tambangan, Perancangan

\section{PENDAHULUAN}

Sumatera Barat memiliki wisata yang cukup banyak dengan alam yang masih terjaga sekaligus dengan adat yang masih kental, terlihat dari adat istiadat yang masih dijunjung tinggi pada di setiap daerah. Banyaknya lokasi wisata di setiap daerah membuat Sumatera Barat menjadi tempat rekreasi keluarga sekaligus tempat refreshing untuk melepaskan penat. Untuk menuju lokasi wisata tidak jarang dijumpai tempat-tempat yang bisa dipakai sebagai penunjang wisata seperti tempat peristirahatan, tempat kebersihan, tempat perbelanjaan, dan sebagainya.

Berdasarkan data Badan Pusat Statistik (BPS) tahun 2018, persentase kunjungan wisatawan ke Sumatera Barat naik cukup signifikan yakni 51,53\%. Banyaknya lokasi wisata di Sumatera Barat sampaisampai ada lokasi bagus tapi tidak terkelola dengan baik karena kurangnya infrastuktur penunjang di area wisata.

Begitu pula yang terjadi di kawasan Lubuak Soda di Kabupaten Tanah Datar dimana memiliki potensi wisata yang dapat dikembangkan. Saat ini, kawasan Lubuak Soda terdapat pemandian yang memiliki sumber air yang sangat jernih. Namun, fasilitas penunjang di kawasan wisata masih sangat minim. Akan lebih baik jika tempat tersebut dikelola dengan baik, dengan diberi fasilitas yang memadai, serta memberikan promosi kepada masyarakat bahwa adanya wisata Lubuak Soda. Dengan banyak wisatawan lokal yang berkunjung ke Lubuak Soda, secara otomatis perekonomian warga disekitar juga akan meningkat.

Pemandian Lubuak Soda sangat menarik dari sisi alamnya, namun dari infrastruktur masih belum memadai. Seperti ruang ganti pakaian untuk pemandian masih terpal yang sederhana, dan juga belum tersedia toilet yang bersih, yang sekarang juga berupa bilik di tengah-tengah sungai, dimana pembuangannya ke sungai. Kemudian dari sisi pedagang yang berjualan juga berantakan, masih belum tertata dengan baik. Selain itu, dalam tempat wisata setidaknya ada musholla bagi orang muslim. Nah ini juga belum ada di objek wisata Lubuak Soda.

Fokus utama dalam penelitian ini adalah membenahi infrastruktur wisata Lubuak Soda dengan mendesain infrastruktur di tempat wisata Lubuak Soda seperti musholla, gazebo, tempat ganti pakaian, dan MCK.

\section{METODE PENELITIAN}

Penelitian ini memberikan uraian pengembangan objek wisata lubuak soda dengan konsep perencanaan. Dalam pelaksanaan penelitian ini ada beberapa metodelogi yang digunakan diantaranya:

Teknik pengumpulan data dengan cara:

a. Observasi

Observasi atau pengamatan langsung dilakukan dengan peninjauan ke lokasi 
wisata Lubuak Soda kabupaten Tanah Datar Provinsi Sumatera Barat.

b. Pengambilan data perencanaan

Data yang dikumpulkan meliputi site plan lokasi, peta, hasil pengukuran, kebutuhan infrastruktur yang belum ada, dan data penunjang lainnya.

c. Wawancara

Wawancara dilakukan dari berbagai sumber seperti masyarakat setempat, pengunjung, dan instansi terkait yang mempunyai wewenang terhadap lokasi lubuak soda.

Data yang telah dikumpulkan baik melalui kunjungan lapangan maupun penelusuran pustaka diatas kemudian dianalisis secara kuantitatif dan kualitatif sehingga menghasilkan konsep perancangan.

\section{HASIL DAN PEMBAHASAN}

Hasil yang diperoleh dalam penelitian ini adalah:

1. Dokumen perencanaan dalam bentuk gambar perencanaan Pembangunan Infrastruktur Objek Wisata Lubuak Soda

2. Dokumen perencanaan dalam bentuk gambar detail perencanaan Pembangunan Infrastruktur Objek Wisata Lubuak Soda

3. Rencana Anggaran Biaya Pembangunan Infrastruktur Objek Wisata Lubuak Soda sebesar Rp. 392,584,000.00



Gambar 1. Pemandian Lubuak Soda

Pemandian lubuak soda tercipta karena adanya pembangunan irigasi melalui dana desa di tahun 2018. Objek pemandian lubuak soda di kelola oleh kelompok sadar wisata (Pokdarwis) Nagari Tambangan. Objek wisata lubuak soda tidak dipungut tiket masuk tapi cukup sumbangan sukarela, tidak ada paksaaan.

Pengunjung lubuak soda tidak hanya di datangi oleh warga lokal saja, tetapi juga dari berbagai daerah. Dengan banyaknya pengunjung yang datang maka banyak masyarakat setempat yang mendadak mengadu untung menjadi pedagang jajanan makanan. Faktor cuaca dingin dan air yang sejuk menambah lapar pengunjung, sehingga kehadiran pedagang masyarakat sekitar sangat mendukung. Namun tidak ada keteraturan berdagang, ditambah tenda-tenda yang berdiri disepanjang jembatan, dan di setiap sudut pemandian.

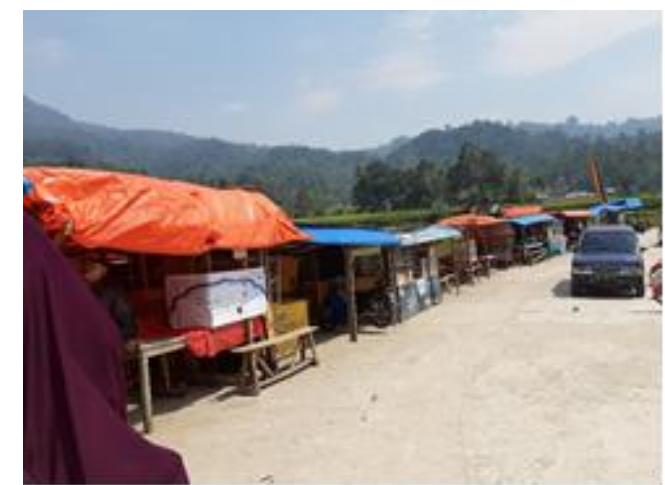

Gambar 2. Tenda-tenda pedagang makanan

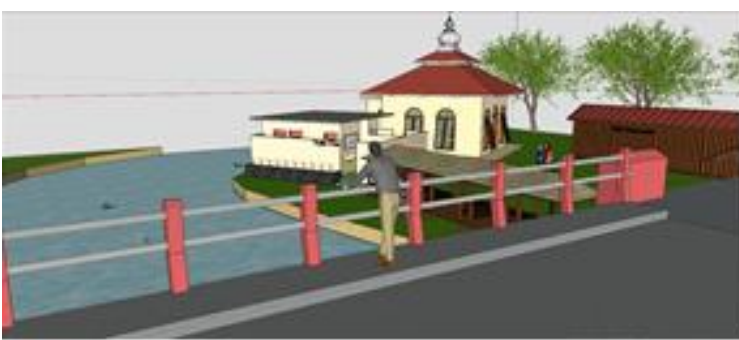

Gambar 3. Rekomendasi Desain Lubuak Soda

Rencana pengembangan tempat jualan disatukan menjadi satu tempat. Yaitu di bawah jembatan, jadi tidak ada lagi yang berjualan di atas jembatan. Dan juga dilengkapi dengan gazebo dan kios cendramata.

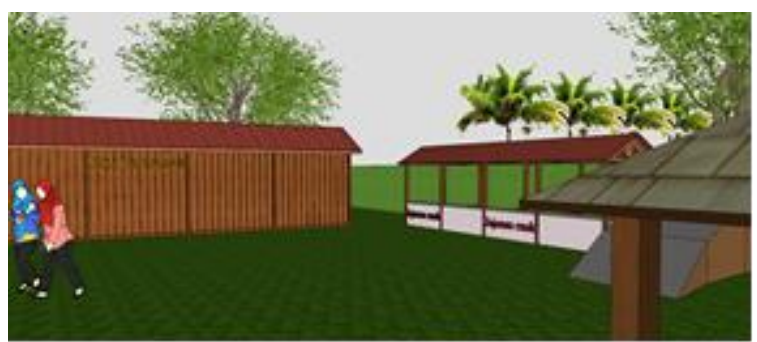

Gambar 4. Rancangan kios jajanan

Saat ini untuk kamar bilas belum ada, yang ada hanya ruang ganti pakaian berupa bilik sederhana yang ditutupi dengan terpal. Begitu juga dengan WC nya yang masih tradisional berdinding terpal dan dengan pemanfaatan air sungai sebagai pembuangan akhir. 


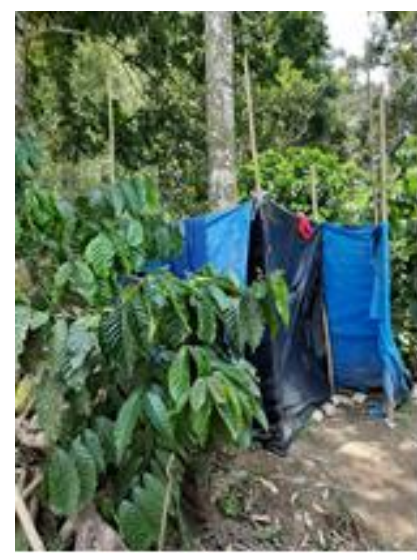

Gambar 5. Kondisi ruang ganti pakaian saat ini

Untuk itu penulis merencanakan desain kamar bilas dan WC seperti gambar dibawah ini. Mengingat luas area terbatas maka cukup dengan 2 buah kamar bilas dan satu WC untuk masing-masing gender.

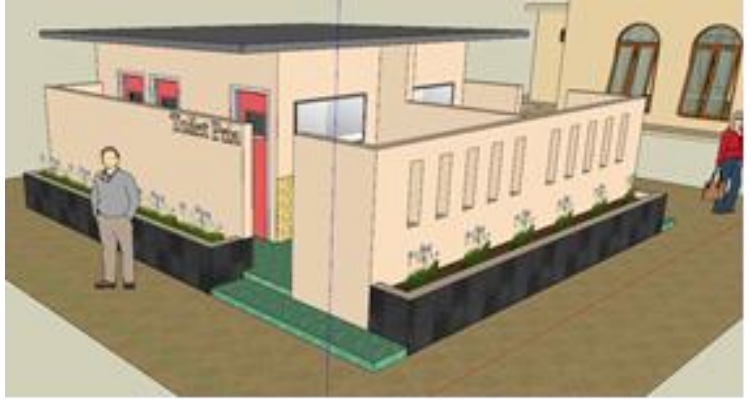

Gambar 6. Rekomendasi Kamar bilas dan WC

Suatu objek wisata yang ramai tentu harus dilengkapi dengan infrastruktur yang lengkap. Salah satu nya yaitu musholla. Ini merupakan kebutuhan bagi pengunjung yang mana kita mayoritas muslim. Saat ini belum ada tersedia musholla. Berikut gambaran musholla untuk objek pemandian lubuak soda.

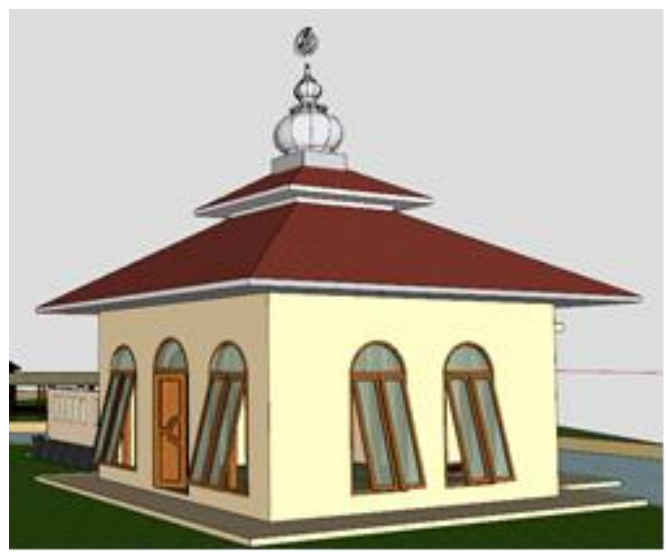

Gambar 7. Rekomendasi desain musholla
Tabel 1. Rekapitulasi Rencana Anggaran Biaya Pengembangan Wisata Lubuak Soda

\begin{tabular}{|c|c|c|}
\hline NO. & $\begin{array}{c}\text { URAIAN } \\
\text { PEKERJAAN }\end{array}$ & $\begin{array}{c}\text { JUMLAH } \\
\text { HARGA (Rp.) }\end{array}$ \\
\hline $\mathbf{A}$ & MUSHOLLA & \\
\hline $\mathrm{I}$ & $\begin{array}{l}\text { Pekerjaan } \\
\text { Pendahuluan }\end{array}$ & $\mathrm{Rp} \quad 3,125,224.00$ \\
\hline II & $\begin{array}{l}\text { Pekerjaan Pondasi } \\
\text { Batu Kali \& Beton }\end{array}$ & Rp $14,816,581.60$ \\
\hline III & $\begin{array}{l}\text { Pekerjaan Beton } \\
\text { Struktur }\end{array}$ & Rp $29,387,352.45$ \\
\hline IV & Pekerjaan Dinding & $\operatorname{Rp} \quad 20,637,876.21$ \\
\hline V & $\begin{array}{l}\text { Pekerjaan Kozen } \\
\text { Pintu Dan Jendela }\end{array}$ & Rp $13,257,094.10$ \\
\hline VI & Pekerjaan Lantai & $\operatorname{Rp} \quad 26,562,573.00$ \\
\hline VII & Pekerjaan Atap & Rp $24,927,218.95$ \\
\hline VIII & Pekerjaan Plapon & $\mathrm{Rp} \quad 12,501,216.00$ \\
\hline IX & Pekerjaan Cat & Rp $\quad 9,064,034.76$ \\
\hline $\mathrm{X}$ & Pekerjaan Listrik & $\mathrm{Rp} \quad 2,305,500.00$ \\
\hline B & TOILET DAN K & BILAS \\
\hline I & $\begin{array}{l}\text { Pekerjaan } \\
\text { Pendahuluan }\end{array}$ & $\mathrm{Rp} \quad 4,051,428.00$ \\
\hline II & $\begin{array}{l}\text { Pekerjaan Pondasi } \\
\text { Batu Kali \& Beton }\end{array}$ & Rp $28,574,835.94$ \\
\hline III & $\begin{array}{l}\text { Pekerjaan Beton } \\
\text { Struktur }\end{array}$ & Rp $48,098,448.66$ \\
\hline IV & Pekerjaan Dinding & $\mathrm{Rp} \quad 43,754,081.13$ \\
\hline $\mathrm{V}$ & Pekerjaan Pintu & $\mathrm{Rp} \quad 4,800,000.00$ \\
\hline VI & Pekerjaan Lantai & Rp $15,626,603.07$ \\
\hline VII & Pekerjaan Cat & Rp $\quad 16,690,294.54$ \\
\hline VIII & Pekerjaan Listrik & $\mathrm{Rp} \quad 2,404,000.00$ \\
\hline C & $\begin{array}{l}\text { PENGADAAN INI } \\
\text { PENUNJANG }\end{array}$ & STUKTUR \\
\hline I & Pengadaan Gazebo & Rp $30,000,000.00$ \\
\hline II & Kios Cendramata & Rp $24,000,000.00$ \\
\hline III & Kios Kuliner & $\mathrm{Rp} \quad 18,000,000.00$ \\
\hline \multicolumn{2}{|c|}{ TOTAL } & Rp 392,584,362.42 \\
\hline \multicolumn{2}{|c|}{ DIBULATKAN } & Rp 392,584,000.00 \\
\hline \multicolumn{3}{|c|}{ Terbilang : } \\
\hline \multicolumn{3}{|c|}{$\begin{array}{l}\text { Tiga Ratus Sembilan Puluh Dua Juta Lima Ratus } \\
\text { Delapan Puluh Empat Ribu Rupiah }\end{array}$} \\
\hline
\end{tabular}

\section{PENUTUP}

Berdasarkan evaluasi lapangan, karena perkembangan yang tidak teratur maka terjadi kesemerawutan tatanan objek wisata Lubuak Soda. Masyarakat melihat potensi ekonomi yang bagus, maka membangun tenda-tenda makanan, namun tempatnya tidak terkelola dengan baik. Infrastruktur Objek wisata lainnya seperti wc dan tempat ganti pakaian belum terbenah dengan baik. Wc masih tradisional memanfaatkan aliran sungai begitu juga tempat ganti pakaian yang masih belum memadai. 
Untuk pengembangan Objek Wisata Lubuak Soda direncanakan penyiapan infrastuktur penunjang Objek wisata Lubuak Soda seperti perencanaan pembangunan kios makanan yang dijadikan satu tempat, perencanaan kamar bilas dan wc, dan tidak lupa perencanaan musholla. Anggaran Biaya yang dibutuhkan untuk merealisasikan perencanaan pengembangan objek wisata lubuak soda adalah sebesar Rp. 392,584,000.00

\section{SARAN}

Untuk pengembangan Objek Wisata Lubuak Soda Pengurus bersama pemerintah setempat harus bekerja sama untuk membangun Objek Wisata Lubuak Soda dengan baik. Pemerintah daerah perlu untuk mengalokasikan dana yang cukup untuk pengembangan pemandian Lubuak Soda sehingga menjadi sektor ungggulan daerah. Masyarakat sekitar juga bisa membuka usaha penyediaan sarana wisata seperti homestay maupun rumah makan atau lainnya.

\section{DAFTAR PUSTAKA}

Maryani, Pengantar Geografi Pariwisata, Jurusan Pendidikan Geografi FPIPS IKIP, 1991.

L. G Schiffman and J. Wisenblit, Consumer Behavior 11ed, Pearson, 2015.

E.C. Hirschman, "Innovativeness, novelty seeking, and consumer creativity," The Journal of Consumer Research, vol. 7, pp. 283-295, December 1980.

Djamarah, Syaiful Bahri dan Aswan Zain, (2002), Strategi Belajar Mengajar, Cetakan Kedua, Jakarta: Rineka Cipta

Alfian YN.2020. Mengenal Objek Wisata Lubuk Soda, Nagari Tambangan http://www.topsumbar.co.id/mengenal-objekwisata-lubuk-soda-nagari-tambangan/ Diakses tanggal 20 Mei 2020 